10 years ESJ

Special edition

\title{
Multimodality and transculturalism in a proposal of a LIBRAS didactic material for hearing people
}

\author{
Kate Mamhy Oliveira Kumada, MA, PhD \\ Universidade Federal do ABC, Brazil \\ Ivani Rodrigues Silva, MA, PhD \\ Universidade Estadual de Campinas, Brazil \\ Fernando Henrique Sato, $B A$ \\ Pontifícia Universidade Católica de Campinas, Brazil \\ Karina Vaneska Pereira de Carvalho, EdS \\ Universidade Federal do ABC, Brazil
}

Doi: $10.19044 /$ esj.2021.v17n22p47

Submitted: 09 November 2020

Accepted: 24 November 2020

Published: 12 July 2021

\author{
Copyright 2021 Author(s) \\ Under Creative Commons BY-NC-ND \\ 4.0 OPEN ACCESS
}

Cite As:

Kumada, K. M. O.; Silva, I. R.; Sato, F. H.; Carvalho, K. V. P. (2021). Multimodality and transculturalism in a proposal of a LIBRAS didactic material for hearing peopl. European Scientific Journal, ESJ, 17 (22), 47. https://doi.org/10.19044/esj.2021.v17n22p47

\begin{abstract}
From the officialization of Brazilian Sign Language (Libras), the deaf person acquires the right to be recognized as a bilingual individual and to ensure this condition, hearing professionals from different areas start to learn Libras, which is even established as a mandatory subject for graduation in some Brazilian higher education courses. Thus, discussions involving the language teaching process, the production of didactic materials, transculturalism and multimodality are necessary for this political and sociolinguistically complex context. From a qualitative research, the objective of this article was to discuss the multimodality and transculturalism present in a proposal for a didactic material to teach Libras in a course involving hearing professionals in the healthcare area. For this purpose, the constructed material considered as legitimate resources the writing of Portuguese, illustrations and photographs of Libras signs, as well as access to videos with different speakers of that language from the scanning of the QR Code incorporated in the material. It is understood that all these elements need to be addressed in an
\end{abstract}


integrated way in the learning of Libras by hearing people, as they constitute the reading of the contemporary world, in which visual and digital resources are also part of the language.

Keywords: Libras, QR Code, Multimodality, Didatic Material

\section{Introduction}

In Brazil, the Brazilian Sign Language (Libras) is officially recognized by the Law 10.436 / 2002 (Brazil, 2002), being the object of study in Applied Linguistics as it is conceived as a language of minority and invisible groups (Cavalcanti, 1999, 2011). The aforementioned law identifies Libras as the linguistic system of the deaf people's communities in the country, and in this political and sociolinguistically complex context (Cavalcanti, 1999, 2011) a variety of speakers are found, in addition to the so-called "native" deaf, such as hearing family members and hearing professionals ${ }^{1}$ (Silva \& Kumada, 2013; Kumada, 2016).

As pointed out by Skutnabb-Kangas (1981), frequently speakers of majority languages learn the language of minority groups as a result of having family members who speak these different linguistic systems or to work with this context and here it is interesting to look specifically at these last ones.

In Brazil, recognition by the legal system of the deaf as bilingual, presupposes their right of access to different spaces of society through respect for Libras as their communication language. To do so, the decree 5626/2005 (Brazil, 2005), which regulates the Law 10436/2002, determines the inclusion of the Libras discipline as mandatory in teacher training and speech therapy courses and as optional in other higher education courses and professional education. This action contributed to the spread of Libras in the country, increasing the contact of hearing professionals (and even the interest of some) with this language. However, with the exception of speech therapy areas, there is little discussion about Libras in the healthcare area, with the largest concentration of research on Libras in the educational and linguistic areas.

In this scope, considering the guarantee of the right to health for deaf people, mentioned in the Libras Law, and the importance of professionals in this area to learn this linguistic system, this research aimed to discuss the

\footnotetext{
${ }^{1}$ According to Behares (2015, p. 132, our translation), this discussion is still the scene of controversies and a challenge to determine the inclusion criteria in deaf communities. Initially, the members of the deaf communities were grouped by the "hearing deficit", but this criteria was refuted due to the different degrees of each individual's hearing loss, as well as disregarding the hearing members who "[...] participate in the sociocultural definers of deafness, while many deaf people outside the community do not have them".
} 
multimodality and transculturalism ${ }^{2}$ present in a proposal for a didactic material to teach Libras in a course involving healthcare professionals.

\section{The research context and its methodological paths}

This is a qualitative research, in which the social interest in inquiry is multidisciplinary and has greater flexibility in adapting the methods for its development (Denzin \& Lincoln, 2006; Pires, 2008). From the perspective of the qualitative approach, with a multi-method support, incursions are made to the applied research (with the generation of a product for the community) (Gil, 2008), as well as to ethnographic research (Erickson, 1984), assuming the participants reflection in this research, inserted in the context of the Libras course, about the production of a didactic material designed for (and requested by) healthcare professionals.

The motivation for this research comes from the experience with a Libras course offered to healthcare professionals linked to a public university in São Paulo's inland cities / Brazil. The course emerged due to the demand of professionals in this field, who received deaf people in their spaces and were unable to understand or meet their needs. It was always necessary to have a family member present at the appointment, which often did not help much, because when he/she knew how to speak Libras, the companion usually presented a daily vocabulary in that language, without the mastery of the health area's technical terms to mediate the dialogue between the deaf and the hearing doctor, when reporting, for example, the symptoms of his complaint, the diagnosis or treatment.

In this course, one of the invited deaf teachers frequently reported the discomfort of the invasive condition that she faced in situations such as gynecological appointments or during her pregnancy, as she was unable to go to her doctor to do prenatal care by herself. She had to take her mother to the appointments with her and, sometimes, she felt deprived of her privacy for having to answer such intimate questions asked by the doctor in front of other people. In her testimonies, she pointed out that she felt like a child being taken to the doctor by her mother. Aware of this situation, when there was a demand from health professionals, efforts were made in order to plan a course that had an adequate methodology, with specific terminology for this area of activity,

\footnotetext{
${ }^{2}$ Aligned with the concept of transculturalism presented by César and Cavalcanti (2007, p. 46), it is understood in this article that "[...] the term transculturalism is considered more appropriate to denaturalize issues of cultural hegemony, with the radical trans seen as a carrier of multi and bidirectional movement sense, and also complementary. The notion of transculturalism applies to a wide range of social phenomena. " (our translation)
} 
but it also included study material that comprised the challenges deaf people face to access these services ${ }^{3}$.

Thus, the construction course of the reported material had as a first step visiting all places in the healthcare area within the university that pointed out the interest in learning Libras: maternity clinic, the emergency room and the medical clinic. After that initial moment in which the professionals' demands were heard, there was a search for more information about the functioning of the place, reading their folders and talking with employees in the section. This provided, to a certain extent, the identification of what was most urgent to be taught, to know, how to receive or welcome the deaf person in the health space, in addition to basic situations that could occur in these spaces. In addition, informal conversations were held with doctors of different specialties and with nurses and attendants to obtain more information about the daily activities that would be addressed, in order to create a glossary to join the Libras course. Based on this information, Libras courses began to be offered and, at the same time, the chapters of a book ${ }^{4}$ that would function as supporting material were organized.

The didactic unit of the material reported in this article had the participation of two researchers from Applied Linguistics, both responsible for teaching Libras in the higher education scope and involved with the referred Libras course for the healthcare area. Additionally, a visual arts professional diagrammed and produced the illustrations in Libras, under the challenge of making a language that is characterized by its dynamism static in images. Then, there was also the participation of a Libras teacher, deaf and master's student, who brought together different deaf speakers and led the production of the videos to be inserted and accessed via QR Code, as it will be discussed later.

\footnotetext{
${ }^{3}$ It should be noted that the group involved with this course had previous experience with this type of action, as it had already developed a similar product requested by the Dentistry area, when a Libras course was implemented and, for this purpose, there was the production of a DVD material entitled "Experiências e Práticas em Libras - Diálogos com Dentistas". This DVD had its content divided into four parts and aimed to support dentists who received deaf people in their offices. This project included some basic guidelines on how the dentist could approach his deaf patient, how to make an anamnesis, how to talk about treatment, among others. The DVD is accompanied by a glossary at the end of each unit with the main signs used in the presented dialogues and also with other important signs in the context mentioned above.

${ }^{4}$ The book would initially have four chapters. One, the first, was under the responsibility of Prof. Dr. Kate Kumada and will be explored in the discussion of this article. The rest of them were drafted, glossaries were implemented, but were not finalized.
} 


\section{Libras didactic material in contemporary times}

The construction of the didactic material took into account the care with the way in which, currently, language teaching in Brazil has been seen as "[...] almost synonymous for adopting and following the contents and techniques of a textbook" (Almeida Filho, 2002, p. 40, our translation), causing great dependence on the part of some language courses teachers. However, although the textbook cannot be seen as "[...] a knowledge holder [...]" (Tilio, 2016, p. 220, our translation) it is a fact that its conscious use can help the teacher in language tuition, working as a scaffold for the construction of relevant language skills and abilities by the student (Tilio, 2016). For this reason, in the materials to be used for this purpose, some principles that guide language teaching in Brazil should be considered, according to the official documents, among them, two points stand out, which follow:

b) To discuss socially relevant issues and to reflect on habits, ways of acting and interacting in different situations and cultures, in confrontation with the own ways of the cultural universe in their surroundings, in order to realize that the world is plural and heterogeneous and understand the role of each one as a citizen;

c) To build knowledge about the studied language, in particular, regarding the different purposes of using that language, according to the different social and regional spheres, based on the status of the partners in interaction, the legitimate place and time and their possible ways of verbal, non-verbal and verbal-visual organization, which refer to a socially and historically recognized purpose; (Tilio, 2016 p. 232, our translation)

In short, these principles demonstrate the importance of the cultural universe plurality that underlies the context of language teaching in which there are different ways of making sense in the world (Tilio, 2016).

In addition, it is necessary to understand that education has also been strongly influenced by advances in the technological / digital and globalized world (Cope \& Kalantzis, 2000). Seeing in these terms, the emergence of new technologies will cause innumerable transformations in the way it is taught and the very conception of text becomes understood not only related to the verbal-written mode, as well as the image becomes an important source for the construction of meanings (Kress, 2004; Lankshear \& Knobel, 2003).

For Ávila-Nóbrega \& Cavalcante (2015), relying on authors such as McNeill (2005), in the field of language acquisition, highlights multimodality as being the matrix force of meanings that allows gesture and speech to be inseparable. Regarding to sign languages, one can glimpse the same matrix of meanings that imposes on Libras to also be considered a multimodal language, 
since gestures, signs and expressions, both manual and non-manual cannot be separated from their matrices of meanings, because they appear simultaneously in the production of meanings.

According to Cavalcanti (2013), although the textbook is a driving force for language teaching, another aspect to be taken into account involves the entire process of training language teachers, practices or didactic materials that are permeated with ideologies that carry the great narratives of modernity. The author warns of the need for linguistic and cultural heterogeneity to be present in these materials, as well as identity reconfigurations inherent to the new flows arising from globalization and its deployments.

Although in recent years the discussion on deaf education has broadened, in general, and in parallel if there is a break with the vision of Brazil as a monolingual country, it is undeniable that, in the context of language teaching, in which superdiversity is present, especially with regard to minority languages, this myth still persists strongly (Vertovec, 2007).

For these reasons, it is understood that when planning the units of a book, it should be verified whether they start from contextualized situations (situated practices) in order to favor learning and its meaning (Almeida Filho, 2002).

According to Almeida Filho (2002, p. 36, our translation), the basis of communicative teaching should have as a premise the organization of experiences mediated by "[...] relevant activities / tasks of real interest and / or the student's need so that he is able to use the target language to perform real actions when interacting with other speakers-users of that language."

Despite these guidelines, in the area of Libras education, however, this is not the case. Many of the didactic materials, available in the country, are restricted to dictionaries, glossaries or a list of signs in that language, such as the book entitled "Saúde em Libras: vocabulário ilustrado - apoio para o atendimento do paciente surdo" or the biology glossary, produced by the Deaf Project (Projeto Surdos) in the Federal University of Rio de Janeiro, which produced three issues addressing the dissemination of scientific signs and the explanation of concepts with videos in Libras involving the themes of Blood, Cell and Immune System (Rumjanek, 2011). These initiatives are praiseworthy for bringing together and expanding the lexicon and language description research, but they do not supply this guiding character for language teaching.

The concept of language teaching based strictly on vocabulary differs from a communicative approach by focusing more on grammatical skills, a problem that affects not only the Libras teaching, but other oral languages as pointed out by scholars of this modality (Leffa, 1998; Almeida -Filho, 2002; Rajagopalan, 2012). 
According to Gesser (2012), when analyzing hearing people learning Libras, it is necessary to understand that vocabulary teaching, traditionally linked to the grammatical approach, is an important component for language acquisition, but it cannot be the only one. Based on Bachman's model (1990 apud Gesser, 2012), linguistic competence can be subdivided into organizational (grammatical and textual) and pragmatic (elocutionary and sociolinguistic) levels. In terms of grammatical competence, there is work with vocabulary, morphology, syntax and phonology / graphology. The signs need to be contextualized, but in addition to grammatical competence, the development of other competences, such as sociolinguistics (pertinent to dialects and linguistic varieties), is also necessary.

\section{A proposal of didactic material for the healthcare area}

Based on the discussion developed so far, the didactic material developed addresses the content of a first contact between the apprentice and Libras, contextualized in the scene of a medical appointment. On this occasion, initially, the student is invited to observe a dialogue illustrated in Libras (Figure 1) and later perform a dynamic with the proposal to register the patient's record (Figure 2). To do so, greetings, alphabet, numbers and other terms that become necessary for dialogue are included in the vocabulary, however, this happens in an integrated way, without being based exclusively on a list of words organized in alphabetical order or semantic category as proposed by most of the materials available for Libras classes. 
Special Edition: 5TH COLLOQUIUM OF THE RESEARCH GROUP BODY AND IMAGE IN DISCOURSE: CECI N'EST PAS UNE PIPE \& 4TH SYMPOSIUM ON TRANSCULTURALITY, LANGUAGE AND EDUCATION: THINKING (AND DOING) OTHERWISE

Figure 1 - Scenes from didactic material dedicated to observing a dialogue in Libras

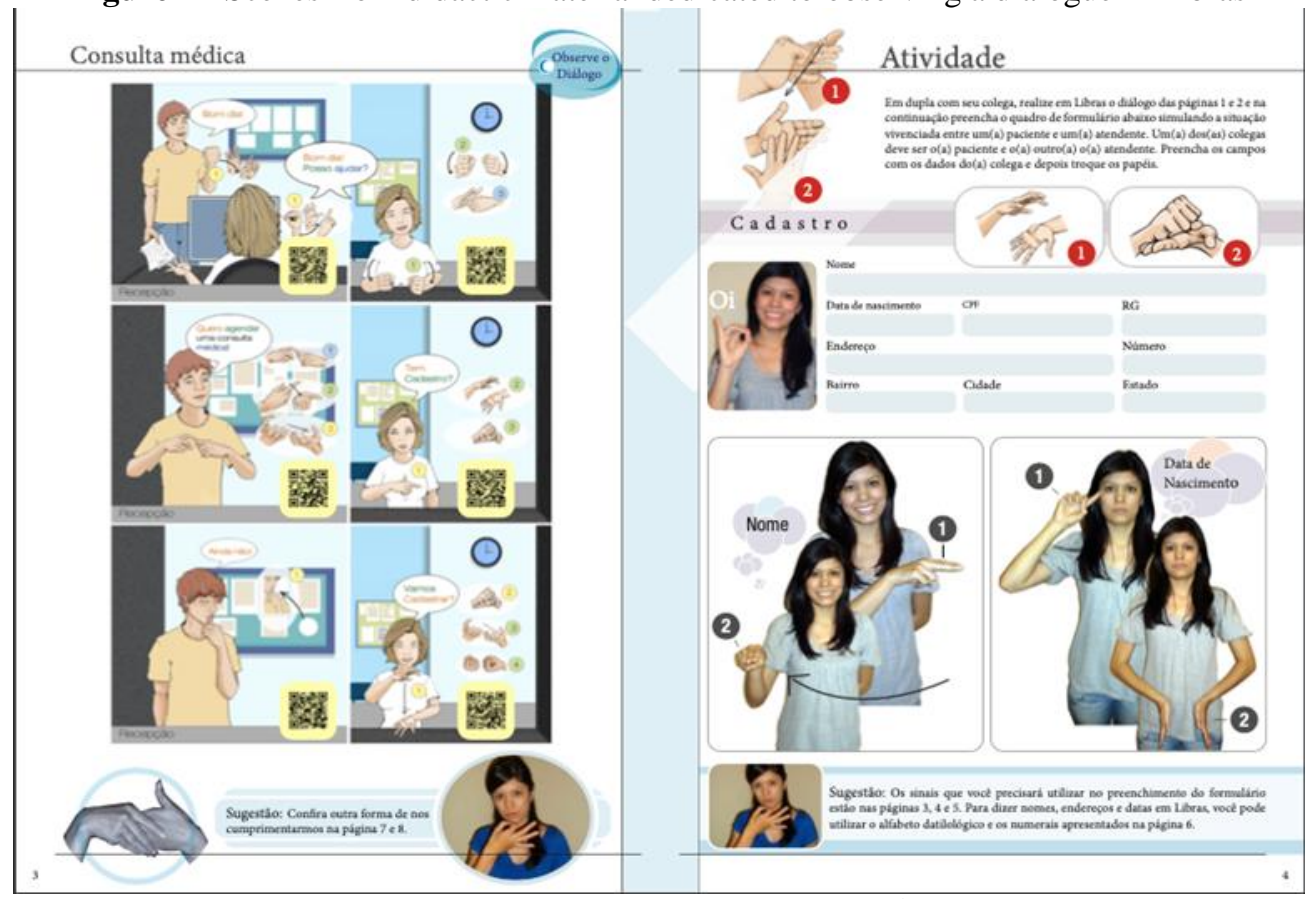

Source: Elaborated by the authors ${ }^{5}$

${ }^{5}$ The didactic material is available on the website of the Research Group registered at CNPq entitled Surdos e Libras - SueLi. Link: http://katekumada.com.br/publicacoes/livros/ 

LANGUAGE AND EDUCATION: THINKING (AND DOING) OTHERWISE

Figure 2 - Scenes from didactic material with the registration activity in Libras

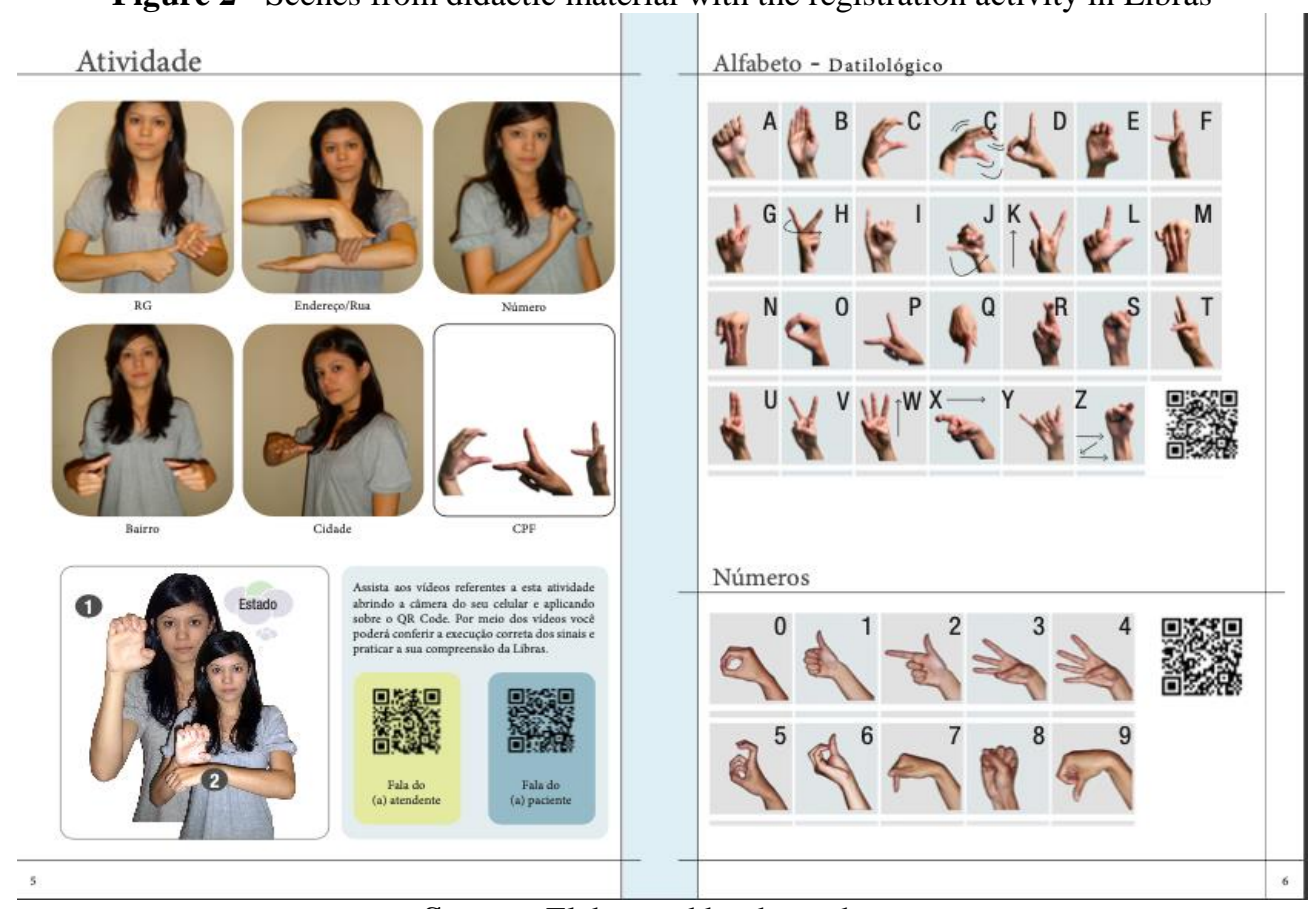

Source: Elaborated by the authors

As can be seen in Figures 1 and 2, the images were constructed from illustrations and photographs, the first ones being developed with realistic hands traits and facial expressions based on adult characters, in order to, respectively, favor the reproduction of the signs in their completeness and provide greater identification by the target audience with the characters portrayed.

The construction of dialogue in the form of comics also allows us to glimpse the intention of making the material visually attractive, using dialog balloons to expand the continuity of the statement in Libras, as well as translating what is being said into Portuguese (a support that can be important to the hearing student who is new to that linguistic system).

To measure this continuity of the statement in Libras, the photographs and illustrations accompany numbers that seek to guide the learner in the sequence of the movements performed (according to Figures 1,2 and 3). Figure 3 shows the representation of different colors for these numbers registered in red and blue circles, which, in turn, were associated with gloss in Portuguese. That way, for example, in the Portuguese phrase "Oi, tudo bem?" ("Hi, how are you?") there is a blue circle related to the word and the sign for "Oi" ("Hi") and a red circle associated with the expression and the sign for 
"tudo bem?" ("how are you?"), since in Libras "tudo bem?"("how are you?") is represented by a single sign.

Furthermore, considering that the learner needs to be in contact with the different linguistic manifestations, arising from the variety of speakers that make up the deaf communities. This concern was solved through the insertion of videos activated by scanning the QR Code, in which the student can check different Libras speakers (five deaf and one hearing speaker) introducing themselves from the learned vocabulary, which allows contact with the varieties of that language, including idiolects and sociolects ${ }^{6}$ (Figures 3 ). The videos are represented by one hearing person, and deaf people of different genders and with different physical characteristics to make the multiplicity of such a sociolinguistic context more explicit.

Figure 3 - Glossary page with greetings accompanied by QR Code

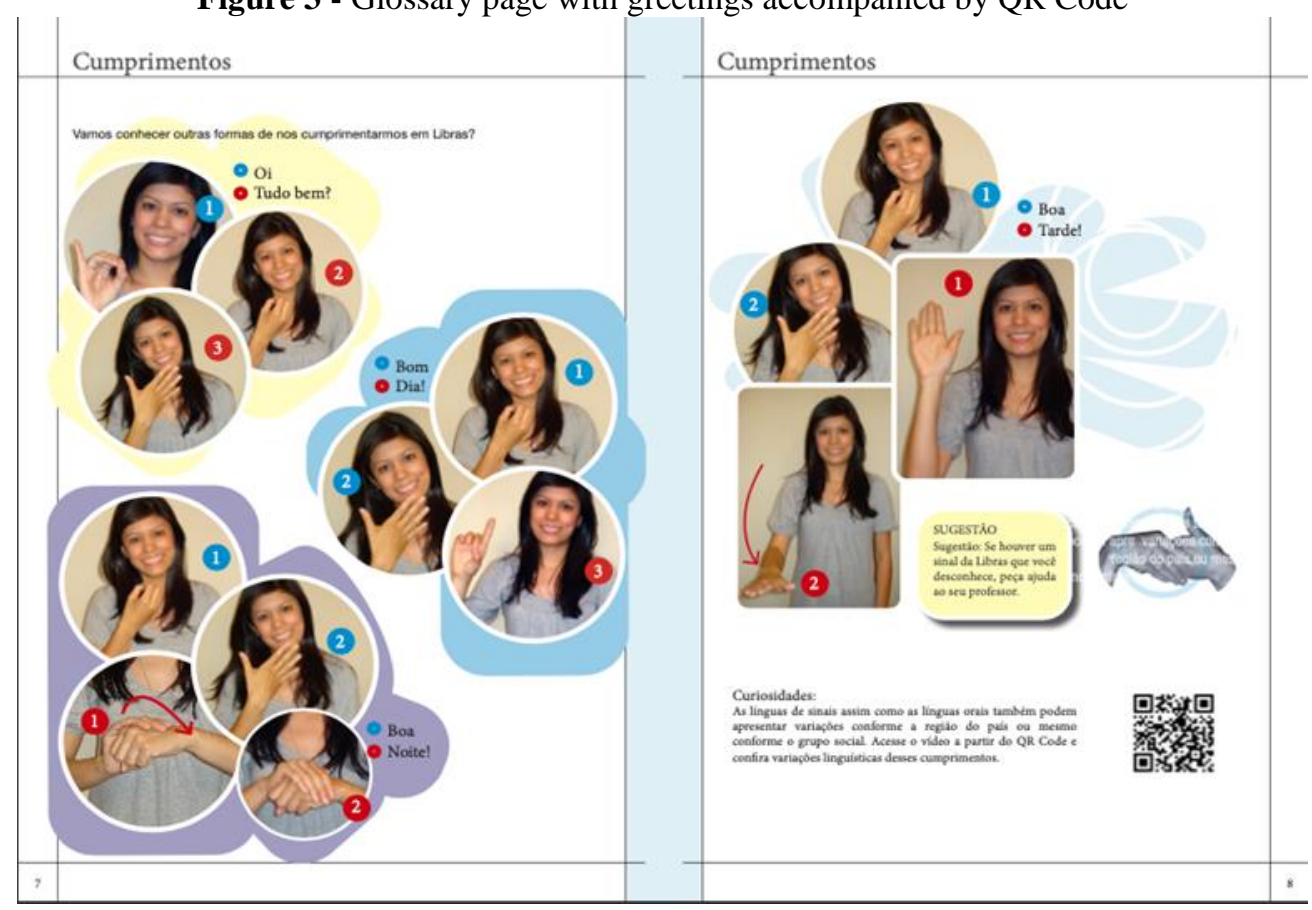

Source: Elaborated by the authors

The recognition of multilingualism in the field of deaf education (Silva \& Kumada, 2013) is linked to the way in which Monte Mór (2010) assumes multimodality. For the author, multimodality is not something new as many may think, since in the natural context all texts or objects are multimodal.

\footnotetext{
${ }^{6}$ It should be noted that the concepts of "linguistic varieties" and "idiolects and sociolects" have been problematized by authors who understand this linguistic plurality, assuming dialects and varieties as languages, thus avoiding asymmetries of power (César \& Cavalcanti, 2007; Garcia \& Leiva , 2014).
} 
When referring to oral languages, the author argues that multimodality has been mistakenly undervalued and considered as extra-linguistic, thereby ignoring:

[...] rhythm, tone of voice, cultural or gender aspects (male or female way of speaking); intonation (if it is within the conventionality of communication or if it is out, altering communication), facial expressions, looks, movements of arms / fingers / body. (Monte Mór, 2010, p. 472, our translation.)

Along this path, the inclusion of videos through the QR Code was the alternative found to contemplate the characteristic of the Libras movement, which illustrations and photographs alone may be insufficient in this regard. However, this concern did not occur only because Libras is a language of a visual, spatial and motor nature, because in line with the discussion of Garcia (2009, p. 143), involving oral languages, it is worth noting that the results of globalization and technological wealth require thinking that "[...] communication includes complex discursive practices with different modalities - visual, audio and spatial, semiotic systems, besides writtenlinguistic modes of meaning [...]", analyzing its use in an integrated way.

Although much is discussed about the importance of visual literacy in teaching Portuguese to the deaf people (Reily, 2003; Lacerda, Santos \& Caetano, 2013), the same multimodality is still little discussed when teaching Libras to hearing people. Aspects such as, for example, non-manual expressions $^{7}$ (incorporated into movements of the face, head, core and lower limbs) are recognized as study objects of Libras grammar (Silva et al., 2020), but the illustrations that accompany the didactic materials of this nature are generally unreliable, represented mostly by a serious expression (neutral).

Based on the criticism of this approach to present Libras to hearing learners, the proposed material is constructed from the perspective of multimodality, since it presents illustrations of the signs, videos (activated by scanning the QR Code) and written Portuguese. Thereby, hearing people are offered the possibility to move between the languages involved, understanding that this is an acceptable way of introducing bilingualism.

It should be noted that the proposal to assume written Portuguese, in a Libras didactic material, considers the absence of a conventional written

\footnotetext{
${ }^{7}$ Non-manual expressions (or non-manual signs) can be associated with Libras' grammar at the lexical and sentimental level. Sentential expressions mark, for example, the statement in its negative, affirmative, interrogative, exclamatory form, as well as conditional and relative clauses, focus and topicalizations. In lexical expressions, among others, it is possible to identify articulators related to intensity, the image of the word in the oral language (lexical oral component), to distinctive features that mark a norm or homonymy (Xavier; 2019; Silva et al., 2020).
} 
system in Libras ${ }^{8}$ and the difficulty of producing images (illustrations or photos) that represent several dialogues in Libras without requiring an infinity of pages. But, this choice is also made by understanding that the learner's language does not need to be abolished in his learning process (Leffa, 1998). In fact, being communicative presupposes understanding the supporting role of the student's mother tongue in learning another language (Almeida Filho, 2002).

Indeed, transit between languages has ceased to be seen as inappropriate in the context of language teaching. According to Garcia and Leiva (2014), the concept of translanguaging has been used to define contexts involving pedagogical practice in which students alternate between English and Welsh in different situations, for example, when writing in one language and reading in another or for question in one language and answer in another. With an emphasis on minority languages speakers, the authors assume, in this concept, the flexibility legitimacy of the linguistic resources use available to the bilingual person.

Nevertheless,

During the LIBRAS teaching to hearing people, most teachers share the belief that the student's mother tongue is not welcome during sign learning, and proclaim loud and clear: "forget the Portuguese language". (Gesser, 2012, p. 114, our translation)

Thus, it is important to emphasize that the presence of multimodality and transculturalism in the recognition of the written Portuguese language in Libras didactic material, therefore, occurred consciously through the recognition of the learning process of health professionals and the languages involved in this context.

\section{Conclusion}

The proposed material considered contributions from Applied Linguistics to the teaching of Libras dedicated to hearing learners, being produced in an interdisciplinary way based on the need and interest shown by health professionals. In this discussion, the characteristics of multimodality, frequently ignored in the teaching of languages, were reinforced, based on the

\footnotetext{
${ }^{8}$ Although Libras can be registered through writing systems such as signwriting, Elis and the word notation system, these are not yet widely used in the country, even among Brazilian deaf people. Thus, when dealing with hearing learners of Libras, we opted to use the written Portuguese register, also for recognizing research in Applied Linguistics, such as the one carried out by Gesser (2006), which demonstrate how the Portuguese writing strategy is repeatedly adopted by hearing students in Libras teaching classes.
} 
appreciation of other representation modes (visual and spatial), whereby the image is no longer considered as merely decorative. It is understood that the sum of the resources used in the textbook build in an integrated way (and no longer complementary) the meanings for the situated linguistic and transcultural practices.

The book unit presented in this article focuses on the context of a medical appointment, but it can be expanded to other themes. It is important to highlight the favoring of technology as an ally to the sign languages teaching, since the use of the QR Code, to generate Libras videos, is still an unprecedented resource in the materials found so far for this purpose. For future work, we also believe in the potential of QR Code markers to be changed, becoming Augmented Reality markers, a promising resource for the sign language approach, since it transcends 2D images and videos, exploring other dimensions that allow a better visualization, for example, of the depth, the configuration of the hand and the facial expressions of some signs.

\section{References:}

1. Almeida Filho, J. C. P. (2002). Dimensões comunicativas no ensino de línguas. (3rd ed.) Pontes.

2. Ávila-Nobrega, P. V., \& Cavalcante, M. C. B. (2015). O envelope multimodal em aquisição de linguagem: momento do surgimento e pontos de mudanças. In, M. C. B. Cavalcante \& E. M. B. Faria (Eds.). Cenas em aquisição da linguagem: Multimodalidade, atenção conjunta e subjetividade (Vol. 1, pp. 11-44). Editora da UFPB.

3. Behares, L. E. (2015). Línguas e identificações: as crianças surdas entre o "sim" e o "não". In C. Skliar (Ed.). Atualidade da educação bilíngue para surdos: Interfaces entre pedagogia e linguística (5th ed., pp. 131147). Mediação.

4. Brasil. (2002, April 25). Lei $n^{\circ} 10.436$, de 24 de abril de 2002. Dispõe sobre a língua brasileira de sinais - Libras e dá outras providências. Diário Oficial [da] União, Seção 1, 23. http://www.planalto.gov.br/ccivil_03/LEIS/2002/L10436.htm.

5. Brasil. (2005, December 23). Decreto $n^{\circ} 5.626$, de 22 de dezembro de 2005. Regulamentada a Lei $\mathrm{n}^{\circ} 10.436$, de 24 de abril de 2002, que dispõe sobre a Língua Brasileira de Sinais - Libras, e o art. 18 da Lei $\mathrm{n}^{\mathrm{o}}$ 10.098, de dezembro de 2000. Diário Oficial [da] União, Seção 1, $28-30$. http://www.planalto.gov.br/ccivil_03/_ato20042006/2005/decreto/d5626.htm

6. Cavalcanti, M. C. (1999). Estudos sobre educação bilíngue e escolarização em contextos de minorias linguísticas no Brasil. Delta: 
Documentação e Estudos em Linguística Teórica e Aplicada, 15(3), 385-417.

7. Cavalcanti, M. C. (2011). Multilinguismo, transculturalismo e o (re)conhecimento de contextos minoritários, minoritarizados e invisibilizados: o que isso tem a ver com a formação de professores e com professores em serviço? In M. C. C. Magalhães \& S. S. Fidalgo (Eds.). Questões de método e de linguagem na formação docente (pp. 171-185). Mercado de Letras.

8. Cavalcanti, M. C. (2013). Educação linguística na formação do professor de línguas: intercompreensão e práticas translíngues. In L. P. Moita Lopes (Ed.). Linguística Aplicada na modernidade recente (pp. 221-226). Parábola.

9. César, A. L., Cavalcanti, M. C. (2007). Do singular para o multifacetado: o conceito de língua como caleidoscópio. In M. C. Cavalcanti \& S. M. Bortoni-Ricardo (Eds.). Transculturalidade, linguagem e educação (pp. 45-65). Mercado de Letras.

10. Cope, B., \& Kalantzis, M. (2000). Multiliteracies: Literacy learning and the design of social futures. Routledge.

11. Denzin, N. K., \& Lincoln, Y. S. (2006). Introdução: a disciplina e a prática da pesquisa qualitativa. In N. K. Denzin \& Y. S. Lincoln. $O$ planejamento da pesquisa qualitativa: Teorias e abordagens (2nd ed., pp. 15-41). Translated by Sandra Regina Netz. Artmed.

12. Erickson, F. (1984, Spring). What makes school ethnography 'ethnographic'? Anthropology; Education Quarterly, 5(1), 51-66. Special Anniversary Issue: Highlights from the past.

13. García, O. (2009). Education, multilingualism and translanguaging in the 21 st century. In A. Mohanty, M. Panda, R. Phillipson \& T. Skutnabb-Kangas (Eds.). Multilingual education for social justice: Globalising the local (pp. 140-158). Orient Blackswan (former Orient Longman).

14. Garcia, O., \& Leiva, C. (2014). Theorizing and enacting translinguaging for social justice. In A. Blackledge \& A. Creese (Eds.). Heteroglossia as practice and pedagogy. Educational Linguistics.

15. Gesser, A. (2006). Um olho no professor e outro na caneta: ouvintes aprendendo a Lingua Brasileira de Sinais. [Doctoral thesis in Applied Linguistics, Instituto de Estudos da Linguagem, Universidade Estadual de Campinas].

16. Gesser, A. (2012). O ouvinte e a surdez: Sobre ensinar e aprender a Libras. Parábola.

17. Gil, A. C. (2008). Métodos e técnicas de pesquisa social (6th ed.). Atlas. 

LANGUAGE AND EDUCATION: THINKING (AND DOING) OTHERWISE

18. Iguma, A., \& Pereira, C. B. (2010). Saúde em Libras: Vocabulário ilustrado - apoio para o atendimento do paciente surdo. Áurea.

19. Kress, G. (2004). Literacy in the new media age. Routledge.

20. Kumada, K. M. O. (2016). Acesso do surdo a cursos superiores de formação de professores de Libras em instituições federais. [Doctoral thesis in Education, Faculdade de Educação, Universidade de São Paulo]. https://www.teses.usp.br/teses/disponiveis/48/48134/tde29032017-112901/.

21. Lacerda, C. B. F., Santos; L. F., \& Caetano, J. F. (2013). Estratégias metodológicas para o ensino de alunos surdos. In C. B. F. Lacerda \& L. F. Santos (Eds.). Tenho um aluno surdo, e agora? Introdução à Libras e educação de surdos (pp. 185-200). Edufscar.

22. Lankshear, C., \& Knobel, M. (2003). New literacies: changing Knowledge and classroom research. Open University Press.

23. Leffa, V. J. (1988). Metodologia do ensino de línguas. In H. I. Bohn \& $\mathrm{P}$. Vandresen. Tópicos em lingüística aplicada: $O$ ensino de línguas estrangeiras (pp. 211-236). Editora da UFSC.

24. Mcneill, D. (2005). Gesture and Thought. University of Chicago Press.

25. Monte Mór, W. (2010, July). Multimodalidades e Comunicação: antigas e novas questões no ensino de línguas estrangeiras. Letras \& Letras, 26(2), 469-476.

26. Pires, Á. P. (2008). Sobre algumas questões epistemológicas de uma metodologia geral para as ciências sociais. In J. Poupart, J. P. Deslauriers, L. H. Groulx, A. Laperrière, R. Mayer \& Á. P. Pires (Eds.). A pesquisa qualitativa: Enfoques epistemológicos $e$ metodológicos (pp. 43-94). Translated by Ana Cristina Nasser. Coleção Sociologia. Vozes.

27. Rajagopalan, K. (2012). O papel eminentemente político dos materiais didáticos de inglês como língua estrangeira. In D. Scheyerl \& S. Siqueira (Eds.). Materiais didáticos para ensino de línguas na contemporaneidade: Contestações e proposições (pp. 57-82). Edufba.

28. Reily, L. H. (2003). As imagens: o lúdico e o absurdo no ensino de arte para pré- escolares surdos. In I. R. Silva, S. Kauchakje \& Z. M. Gesueli (Eds.). Cidadania, surdez e linguagem: Desafios e realidades (pp. 161-192). Plexus.

29. Rumjanek, J. B. D. (2011). Novos sinais para a ciência: Desenvolvimento de um glossário científico em Libras. [Master's dissertation in Biological Chemistry, Instituto de Bioquímica Médica, Universidade Federal do Rio de Janeiro].

30. Silva, E. P., Costa, P. D. P., Kumada, K. M. O., \& De Martino, J. M. (2020). SILFA: Sign Language Facial Action database for the 
development of assistive technologies for the deaf. In Annals, 15th IEEE International Conference on Automatic Face and Gesture Recognition (pp. 382-386), Buenos Aires. Washington: Institute of Electrical and Electronics Engineers (IEEE).

31. Silva, I. R.; Kumada, K. M. O. (2013, July). Representações sobre o contexto multilíngue da surdez. Interdisciplinar, 19(1), 99-114.

32. Skutnabb-Kangas, T. (1981). Bilingualism or not: The education of minorities. Translated by Lars Malmberg and David Crane. Multilingual Matter.

33. Tilio, R. (2016). O livro didático no ensino de línguas: caracterização do objeto, funções e critérios de escolha. In A. L. E. Chaves,, N. A. C., Teno \& S. D. Araujo (Orgs). Manifestações: Ensaios críticos de língua e literatura. Apis.

34. Vertovec, S. (2007, November). Super-diversity and its implications. Ethnic and Racial Studies, 30(6), 1024-1054.

35. Xavier, A. N. (2019). Análise preliminar de expressões não-manuais lexicais na libras. Intercâmbio, 41, 41-66. 